\title{
Forecasting river bank erosion with regards to rainfall erosivity and soil erodibility
}

\author{
Y. Naimah \& Z. A. Roslan \\ Infrastructure University Kuala Lumpur, Malaysia
}

\begin{abstract}
Riverbank erosion is one of the major and unpredictable problems worldwide. The erosion involves the wearing away of soil found along the river bed and it can take place due to the occurrence of heavy rainfall, strong stream flow and weak river bank soil. The purpose of this study is to categorise the river bank erosion at the study area based on two main factors, namely, rainfall erosivity and soil erodibility. With rainfall data records for 9 rainfall stations along Langat River, a daily rainfall amount analysis and 'ROSE' index software application (after the name of the researcher ROSlan and Ezanie) were used to forecast the erosion risk potential along the Langat River bank. The results indicate that the highest rainfall erosivity is from the month of March to April and September to November. The soil resistance against erosion, termed as soil erodibility, depends on several factors, such as soil textural composition, soil infiltration level and organic matter content. Sieve analysis and hydrometer tests were conducted for all the soil samples collected at every $2 \mathrm{~km}$ interval on both sides of the river bank and the "ROM" scale (after the name of researcher ROslan and Mazidah) is used to determine the degree of soil erodibility, namely low, moderate, high, very high and critical. The results indicate that the soil erodibility with a high, very high and critical category for both sides of Langat River bank were at the upper and middle stream of Langat River, which is in the Hulu Langat and Sepang districts. Thus, this would benefit the country in terms of cost reduction in river bank protection; besides, the relevant authorities can take early measures to overcome river bank erosion failure.
\end{abstract}

Keywords: river bank, soil erodibility, rainfall erosivity, soil texture. 


\section{Introduction}

In recent years there has been an increasing concern over soil erosion in many river systems in Malaysia. Rivers that flow through densely populated areas including towns and housing estates are often polluted with solid waste and eroded soil resulting in pollution levels incapable of sustaining aquatic life let alone blockages that cause flash flood. Floods occur when water overflows from a river to a plain, which is normally dry, and covers it. Erosion occurs naturally when, during rainfall, water in the river flows rapidly thereby eroding the river banks. Eventually the river banks collapse, forming silt on the base of the river.

The river bank erosion takes place after an occurrence of flood due to heavy rainfall, strong stream flow and weak river bank soil. The rainfall potential in causing erosion is determined according to rainfall erosivity which means the ability of rainfall to erode the soil. The characteristic of the erosive properties of rainfall such as rainfall amount, duration, intensity, raindrops (size velocity and shape), kinetic energy and seasonal distribution of the rain are the factors that have a great influence on soil erosion [1]. The higher the rainfall erosivity, the greater the potential of rainfall induces erosion that can lead to river bank erosion. The amount of soil erosion loss is then going to depend upon the combination of the strength of the rain to cause erosion and the ability of the soil to withstand the rain. The resistance in the soil against erosion is called as soil erodibility and the value depends on several factors such as the level of infiltration, organic matter content and the structure of soil.

The river bank erosion will lead to the accumulation of sediment which in turn will increase the river pollution problem. The capacity to carry away sediments depends on the rate at which water flows in the river. When the river flow is fast, the sediment movement will increase. During rainfall, sediments and eroded soil are flushed out to the downstream and sedimentation will take place, resulting to the rivers become milky and the downstream become shallower. This situation leads to water scarceness, flash flood and other environmental problems.

The best known model in evaluating the amount of erosion loss is the Universal Soil Loss Equation (USLE) [2] (as shown in equation (1)). This model expressed mathematically all variable factors that influenced soil erosion, such as rainfall erosivity, soil erodibility, topography and soil conservation practices. It estimates the total soil loss due to sheet and rill erosion on a single slope and does not account for any additional losses that may occur from gully erosion and erosion by wind.

Hence, it is important to carry out a study on rainfall erosivity and soil erodibility since these are the main factors that contribute to river bank erosion.

$$
\mathrm{A}=\mathrm{R} \times \mathrm{K} \times \mathrm{LS} \times \mathrm{C} \times \mathrm{P}
$$

where

$$
\begin{aligned}
& \mathrm{A}=\text { Annual soil loss (t/ha.yr) } \\
& \mathrm{R}=\text { Rainfall erosivity factor (MJ.mm/ha.hr) } \\
& \mathrm{K}=\text { Soil erodibility factor (t.hr/(MJ.mm)) }
\end{aligned}
$$


$\mathrm{LS}=$ Slope length and steepness factor

$\mathrm{C}=$ Crop management factor

$\mathrm{P}=$ Conservation practice factor.

\section{Rainfall erosivity: $\mathbf{R}$ factor}

Rainfall erosivity is an erosive power of rainfall to cause soil loss. There are several factors that persuade the erosivity of rain, such as the rain intensity, duration, the level of rain velocity and size of raindrops. The kinetic energy of rainfall resulted from large drop was very high compared to small drops due to the drop mass increases exponentially with diameter and the raindrop fall velocity has a nonlinear relationship with drop diameter [3]. A study on rainfall erosivity in Southeastern Nigeria was conducted and it had been found that the kinetic energy of the rains contributes the major causes of soil detachment and enhancing the erosion process [4]. It has been identified that the erosive rainfall was gradually declining in rainfall amount from the southern part of the north of Nigeria.

The best single rainfall related to soil loss is the product of total rainfall energy of a storm and its maximum 30 minute rainfall amount [5]. The mathematical equation of rainfall erosivity, $\mathrm{R}$ is stated in equation (2).

$$
\mathrm{R}=\mathrm{Ex} \mathrm{I} \mathrm{I}_{30}
$$

where $\mathrm{E}=$ rainfall kinetic energy; $\mathrm{I}_{30}=30$ minutes maximum rainfall amount.

The equation which relates rainfall kinetic energy and its intensity as can be seen in equation 3 and 4.

$$
E=210+89 \log _{10} I
$$

where

$$
\mathrm{I}=\sum \frac{\text { Rainfall Amount }}{\text { Rainfall Duration }}
$$

An alternative method to determine rainfall erosivity is "ROSE" index. The rainfall erosivity categories with respect to the ROSE index are shown in Table 1. By using the 'ROSE' index, the rainfall data taken from the nearby rainfall stations of the studied site will be analysed and categorised accordingly with respect to its rainfall erosivity values. This index can be applied universally since the rainfall data are available at any automatic rainfall gauge stations throughout the world.

Table 1: $\quad$ Category of the "ROSE" index.

\begin{tabular}{|c|c|}
\hline ROSE index (MJ.mm/ha.hr) & Category \\
\hline$<5000$ & Low \\
\hline $5000-10000$ & Moderate \\
\hline $10000-15000$ & High \\
\hline $15000-20000$ & Very high \\
\hline$>20000$ & Critical \\
\hline
\end{tabular}




\section{Soil erodibility: $K$ factor}

The soil erodibility factor ( $\mathrm{K}$-factor) is a quantitative description of the inherent erodibility of a particular soil. It is a measure of the susceptibility of soil particles to detachment and transport by rainfall and runoff. For a particular soil, the soil erodibility factor is the rate of erosion per unit erosion index from a standard plot. The factor reflects the fact that different soils erode at different rates when the other factors that affect erosion namely infiltration rate, permeability, total water capacity, dispersion, rain splash, and abrasion are the same. Texture is the principal factor affecting the soil erodibility, but structure, organic matter, and permeability also contribute.

The soil erodibility also can be described as the resistance of soil towards the detachment and transportation by erosive agents [6]. It is an important index to determine the soil sensitivity towards erosion. The erodibility study on the Loess Plateau of China found that the erodibilty able to isolate the effects of soil properties on soil loss and does not depend on topographical factor such as slope steepness [7]. In this study, $\mathrm{K}$ factor values were derived using nomograph and field measurement that involved laboratory analysis of soil samples.

Many attempts have been made to devise a simple index of erodibility based either on the properties of the soil as determined in the laboratory or the field, or on the response of the soil to rainfall. Theoretically the use of clay content as an indicator of erodibility was found to be more satisfying, when the clay particles combine with organic matter to form soil aggregates or clods. It is the stability of these which determines the resistance of the soil [8]. The clay ratio (as shown in Equation (1)) to determine the Bouyoucos erodibility index [9], has led to the development of $\mathrm{EI}_{\mathrm{ROM}}$ equation.

$$
\text { Bouyoucos erodibility index }=\frac{\% \text { of Sand }+\% \text { of Silt }}{\% \text { of Clay }}
$$

An advanced and new improved soil erodibility index was then developed by the name of $\mathrm{EI}_{\mathrm{ROM}}$ or 'ROM' Scale [10]. This new equation is still using the original principal of Bouyoucos which is analyzing the soil textural composition of sand, silt and clay. The new equation clearly had shown the significant value and threshold for soil erodibility demarcation and at the same time indicate the expected erosion feature. With the new $\mathrm{EI}_{\mathrm{ROM}}$ equation as in Equation (6), the more realistic and significant value of soil erodibility index can be used simultaneously with its risk category (as shown in Table 2), to indicate the degree of soil erodibility.

$$
\mathrm{EI}_{\mathrm{ROM}}=\frac{\% \text { Sand }+\% \text { Silt }}{2(\% \text { Clay })}
$$


Table 2: 'ROM' Scale with regards to the soil erodibility category.

\begin{tabular}{|c|c|}
\hline 'ROM' scale & Soil erodibility category \\
\hline$<1.5$ & Low \\
\hline $1.5-4.0$ & Moderate \\
\hline \hline $4.0-8.0$ & High \\
\hline $8.0-12.0$ & Very High \\
\hline \hline 12.0 & Critical \\
\hline
\end{tabular}

\section{Methodology}

In this research, nine (9) rainfall stations along Langat River have been selected to be analysed (as shown in Table 3). The daily rainfall data of the studied areas were obtained from the Department of Irrigation and Drainage (DID) Malaysia, Ampang. The data shows the total, minimum and maximum daily rainfall amount for each month of the study duration. The daily rainfall data was analysed by using Daily of Rainfall Amount (DORA) and automatically generated the total number of rainy days, number of days with rainfall less than $20 \mathrm{~mm}$, number of days equal or more than $20 \mathrm{~mm}$ and the percentage of erosive

Table 3: Rainfall stations along Langat River.

\begin{tabular}{|c|c|c|c|c|c|}
\hline \multirow[b]{2}{*}{ No } & \multicolumn{5}{|c|}{ Rainfall station } \\
\hline & Station No & $\begin{array}{l}\text { Station } \\
\text { Name }\end{array}$ & Latitude & Longitude & District \\
\hline 1 & 3218101 & $\begin{array}{c}\text { TNB } \\
\text { Pansoon }\end{array}$ & $03^{\circ} 12^{\prime} 34.7^{\prime \prime}$ & $101^{\circ} 52^{\prime} 33.1^{\prime \prime}$ & \multirow{5}{*}{$\begin{array}{l}\text { Hulu } \\
\text { Langat }\end{array}$} \\
\hline 2 & 3017105 & Sg Raya & $03^{\circ} 04^{\prime} 04^{\prime \prime}$ & $101^{\circ} 46^{\prime} 19^{\prime \prime}$ & \\
\hline 3 & 3017106 & Sg Serai & $03^{\circ} 05^{\prime} 58^{\prime \prime}$ & $101^{\circ} 47^{\prime} 51^{\prime \prime}$ & \\
\hline 4 & 3017108 & Sg Balak & $03^{\circ} 00^{\prime} 59^{\prime \prime}$ & $101^{\circ} 45^{\prime} 49^{\prime \prime}$ & \\
\hline 5 & 2816041 & Dengkil & $02^{\circ} 51^{\prime} 20.8^{\prime \prime}$ & $101^{\circ} 40^{\prime} 53.1^{\prime \prime}$ & \\
\hline 6 & 2617134 & $\begin{array}{l}\text { Ladang } \\
\text { Sepang }\end{array}$ & $02^{\circ} 40^{\prime} 15^{\prime \prime}$ & $101^{\circ} 43^{\prime} 45^{\prime \prime}$ & Sepang \\
\hline 7 & 2816114 & $\begin{array}{l}\text { RTB Bukit } \\
\text { Changgang }\end{array}$ & $02^{\circ} 48^{\prime} 41^{\prime \prime}$ & $101^{\circ} 39^{\prime} 15^{\prime \prime}$ & \multirow{3}{*}{$\begin{array}{l}\text { Kuala } \\
\text { Langat }\end{array}$} \\
\hline 8 & 2815001 & $\begin{array}{c}\text { JPS Sg } \\
\text { Manggis }\end{array}$ & $02^{\circ} 49^{\prime} 35^{\prime \prime}$ & $101^{\circ} 32^{\prime} 30^{\prime \prime}$ & \\
\hline 9 & 2914122 & $\begin{array}{c}\text { Bt } 9 \\
\text { Sijangkang }\end{array}$ & $02^{\circ} 57^{\prime} 23^{\prime \prime}$ & $101^{\circ} 26^{\prime} 03^{\prime \prime}$ & \\
\hline
\end{tabular}


rainfall. The dates which are categorised as high, very high and critical were noted down and requested for the 10 minutes data interval. The final stage of rainfall analysis was analysed the rainfall erosivity of the rainfall events by using "ROSE" index software. Meanwhile, a total of 120 soil samples were collected for every $2 \mathrm{~km}$ interval using a hand auger for the depth of $1 \mathrm{~m}$ along the Langat River. In this study, disturbed samples are required for detail lab testing on its particle size in order to determine the amount of sand, silt and clay. Particle size analysis is the standard laboratory procedure for the determination of the particle size distribution of a soil. Soil consists of an assembly of ultimate soil particles which is discrete particles of various shapes and sizes. The laboratory testing namely sieve analysis and hydrometer test were conducted to analyse the percentage of soil textural composition and the data was used to determine the erodibility index according to "ROM" Scale as stated in equation 6 and this will indicate the erosion risk degree based on Table 2 as low, moderate, high, very high and critical.

\section{Results and discussion}

The total of daily rainfall amount equal or more than $20 \mathrm{~mm} /$ day along Langat River was shown in Figure 1. It is an early warning to show the potential of soil erosion risk within the coverage area of $25 \mathrm{~km}$ radius. It can be seen that the highest possibility of rainfall erosivity risk based on daily rainfall amount are in March, April and November whereby the lowest risk were in the months of June and July. These findings were consistent with the annual monsoons in Malaysia which is from Southwest and Northeast which started from April to October and from October to March respectively. The assessment of rainfall erosivity was

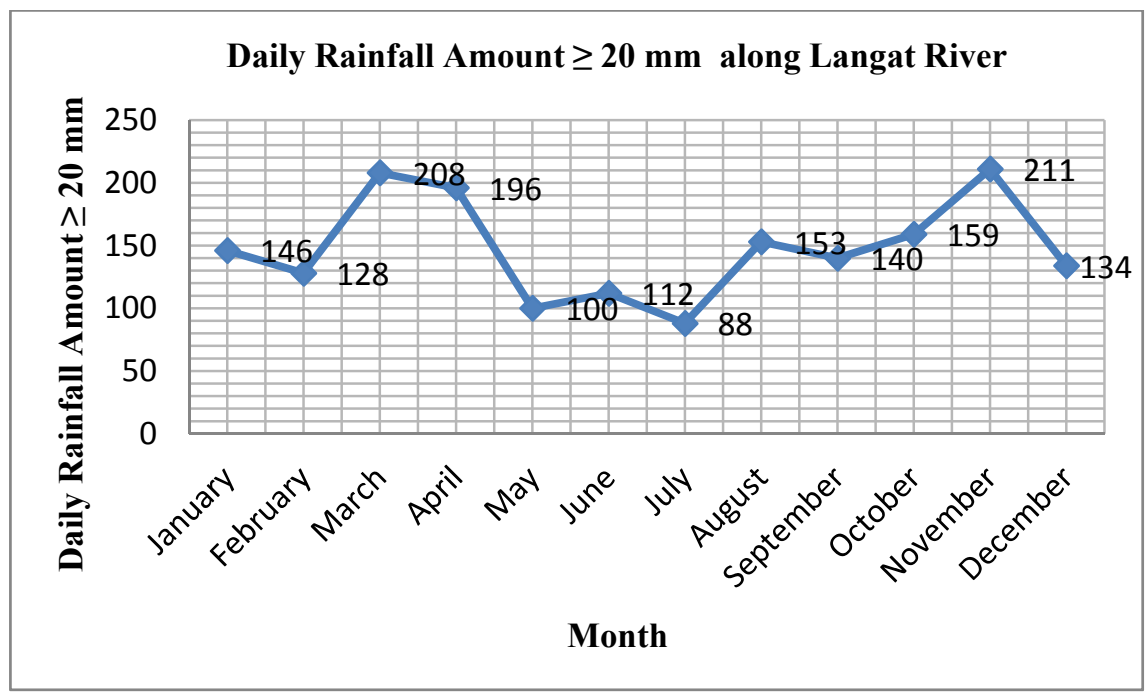

Figure 1: Daily rainfall amount $\geq 20 \mathrm{~mm}$ along Langat River. 
based on every 10 minutes rainfall data interval which has been categorised as low, moderate, high, very high and critical. The percentage of rainfall risk for each category for Hulu Langat, Sepang and Kuala Langat district respectively were shown in Table. The seriousness of rainfall erosivity was determined by summation of high, very high and critical category of rainfall erosivity. It can be seen that the total percentage of high, very high and critical rainfall erosivity risks for Hulu Langat, Sepang and Kuala Langat were 28.00\%, 20.00\% and $23.04 \%$ respectively. It shows that the possibility of soil erosion with regards to rainfall erosivity is more at Hulu Langat district compared to Kuala Langat and Sepang. The degree of accuracy of rainfall erosivity assessment is more reliable since it includes rainfall intensity and energy.

Table 4: Rainfall erosivity along Langat River.

\begin{tabular}{|c|c|c|c|c|}
\hline Districts & \multicolumn{3}{|c|}{ Percentage of rainfall erosivity } & \\
\hline & High & Very high & Critical & Total \\
\hline Hulu Langat & 15.60 & 6.00 & 6.40 & 28.00 \\
\hline Sepang & 13.00 & 7.00 & 0.00 & 20.00 \\
\hline Kuala Langat & 12.00 & 5.70 & 5.70 & 23.04 \\
\hline
\end{tabular}

Table 5: A typical soil textural composition along Langat River.

\begin{tabular}{|c|c|c|c|c|c|c|c|}
\hline \multirow[b]{2}{*}{ No } & \multirow{2}{*}{\multicolumn{2}{|c|}{ Sample }} & \multicolumn{3}{|c|}{ Soil textural composition } & \multirow[b]{2}{*}{$\begin{array}{l}\text { "ROM } \\
\text { scale" }\end{array}$} & \multirow[b]{2}{*}{$\begin{array}{l}\text { Degree of } \\
\text { erosion }\end{array}$} \\
\hline & & & $\begin{array}{l}\text { Sand } \\
(\%)\end{array}$ & $\begin{array}{l}\text { Silt } \\
(\%) \\
\end{array}$ & $\begin{array}{l}\text { Clay } \\
(\%)\end{array}$ & & \\
\hline 1 & \multirow{2}{*}{ HA38 } & Left & 16.98 & 73.99 & 2.99 & 15.22 & Critical \\
\hline 2 & & Right & 10.98 & 56.68 & 3.14 & 10.78 & Very high \\
\hline 3 & \multirow{2}{*}{ HA39 } & Left & 12.22 & 76.85 & 3.89 & 11.44 & Very high \\
\hline 4 & & Right & 12.46 & 79.78 & 3.22 & 14.31 & Critical \\
\hline 5 & \multirow{2}{*}{ HA40 } & Left & 11.70 & 75.61 & 4.41 & 9.90 & Very high \\
\hline 6 & & Right & 14.14 & 78.24 & 4.90 & 9.43 & Very high \\
\hline 7 & \multirow{2}{*}{ HA41 } & Left & 11.24 & 73.04 & 9.70 & 4.35 & High \\
\hline 8 & & Right & 12.28 & 76.18 & 6.58 & 6.72 & High \\
\hline 9 & \multirow{2}{*}{ HA42 } & Left & 0.10 & 59.28 & 40.62 & 0.73 & Low \\
\hline 10 & & Right & 0.20 & 69.90 & 25.90 & 1.17 & High \\
\hline
\end{tabular}

Meanwhile, the results of laboratory test which is the percentages of soil textural composition, "ROM" Scale value and the erosion risk classification were tabulated as shown in Table 5. The percentage of soil textural composition and degree of erosion of Langat River in Hulu Langat District are summarised in Figure 2. It can be seen that the erosion risk on the left bank of the study area was categorised as $59.00 \%, 9.00 \%, 9.00 \%$ and $23.00 \%$ of critical, very high, high and moderate classification respectively. Meanwhile the erosion risk on the 
right bank of the study area was recorded at $40.90 \%, 4.50 \%, 40.90 \%, 9.10 \%$ and $4.50 \%$ of critical, very high, high, moderate and low category respectively. It shows that the left bank of Langat River in Hulu Langat district experienced more erosion risk compared to the right bank. The results indicate that the soils with smaller particles (silt and clay) have a larger surface area than those with larger sand particles, and a large surface area allows a soil to hold more water. In other words, a soil with a high percentage of silt and clay particles, which is categorised as fine soil, has a higher water holding capacity and has a greater erodibility than a sandy soil.

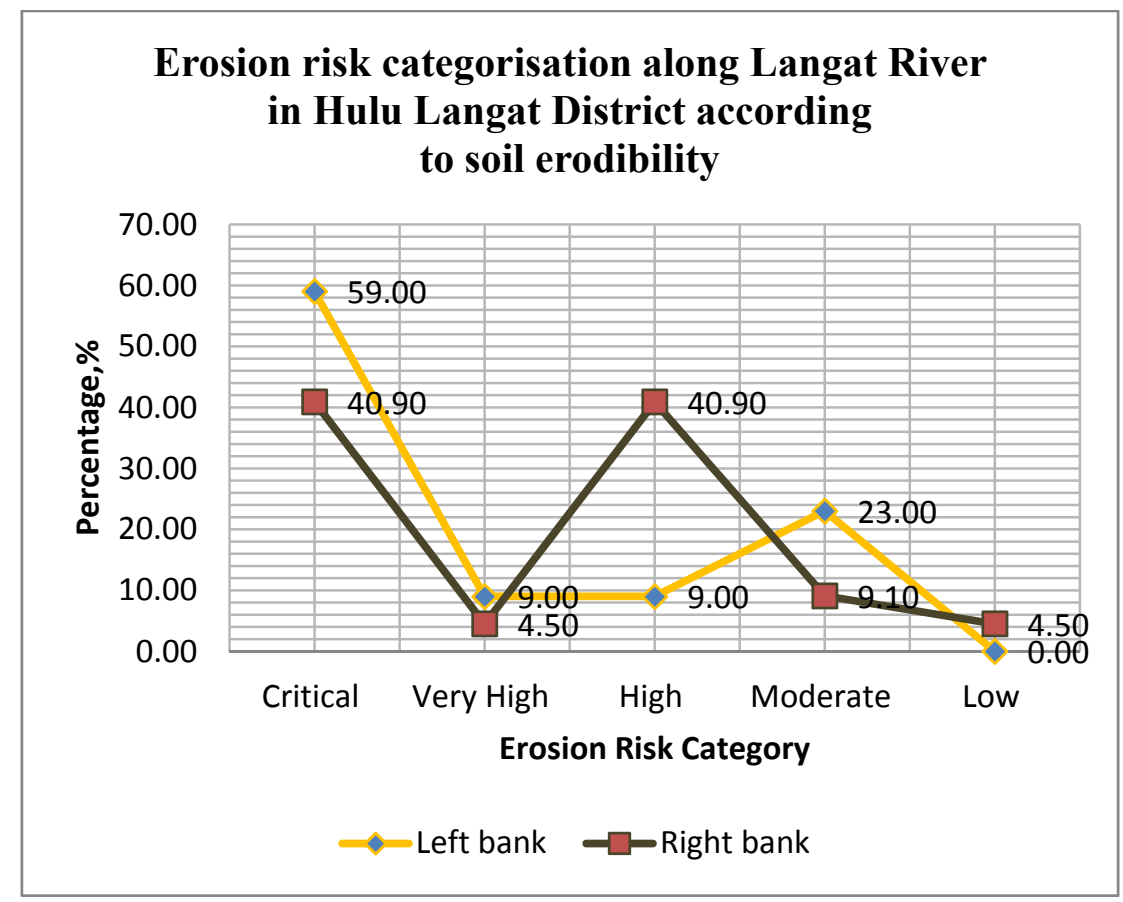

Figure 2: Erosion risk along Langat River in Hulu Langat district.

The seriousness of erosion risk on the left and right bank of Langat River in Sepang district according to "ROM" scale can be seen in Figure 3. It shows that $62.50 \%$ of the soil samples on the left bank of Langat River at Sepang district were classified as critical erosion risk. Meanwhile, only $50.00 \%$ of the soil samples on the right bank of the study area were categorised as critical erosion risk. Besides that, there was no low category of erosion risk found on the left bank of Langat River in Sepang district. The results indicate that the left bank of Langat River in Sepang district recorded the higher risk of erosion.

It is because the soil on the left bank of Langat River is composed of higher percentage of sand compared to the right bank of Langat River. Sandy soils are well known as low cohesive force and therefore are more prone to detachment 
and transportation by water. Furthermore, high sandy soil content encourages high rate of permeability of water into the soil which induces the erosion. It can be concluded that the more sandy a soil, the easier it will erode.

The erosion risk categorisation of Langat River in Kuala Langat District can be seen in Figure 4. It can be seen that the erosion risk on the left bank of the

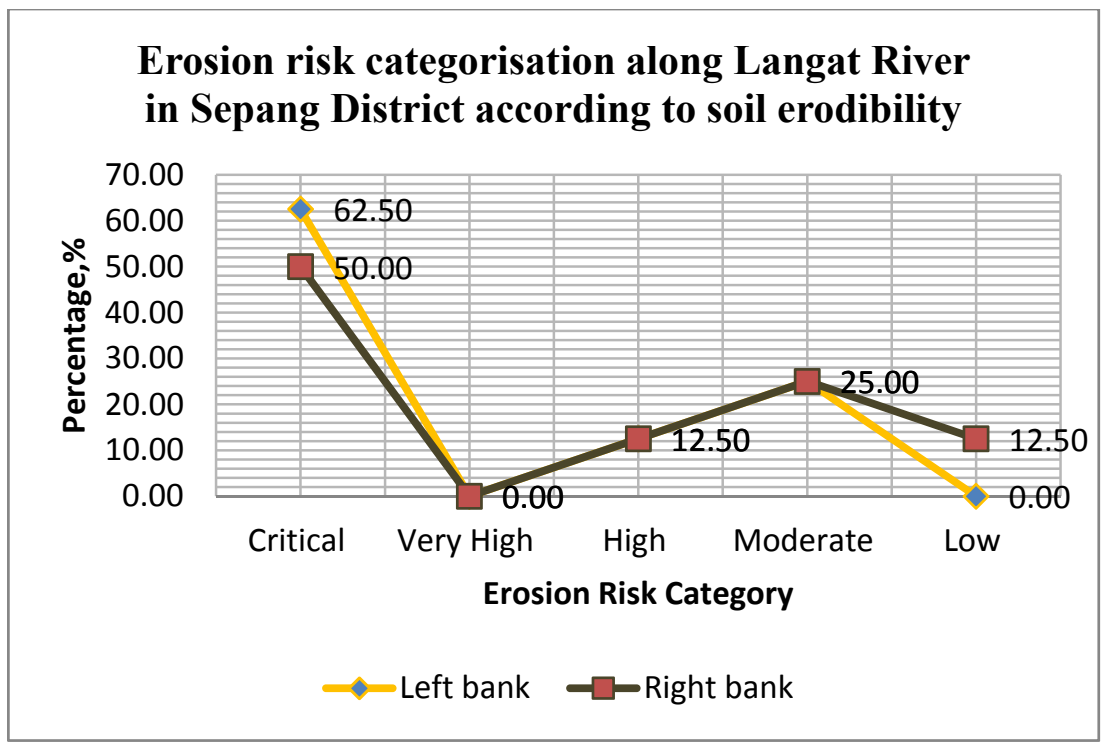

Figure 3: Erosion risk along Langat River in Sepang district.

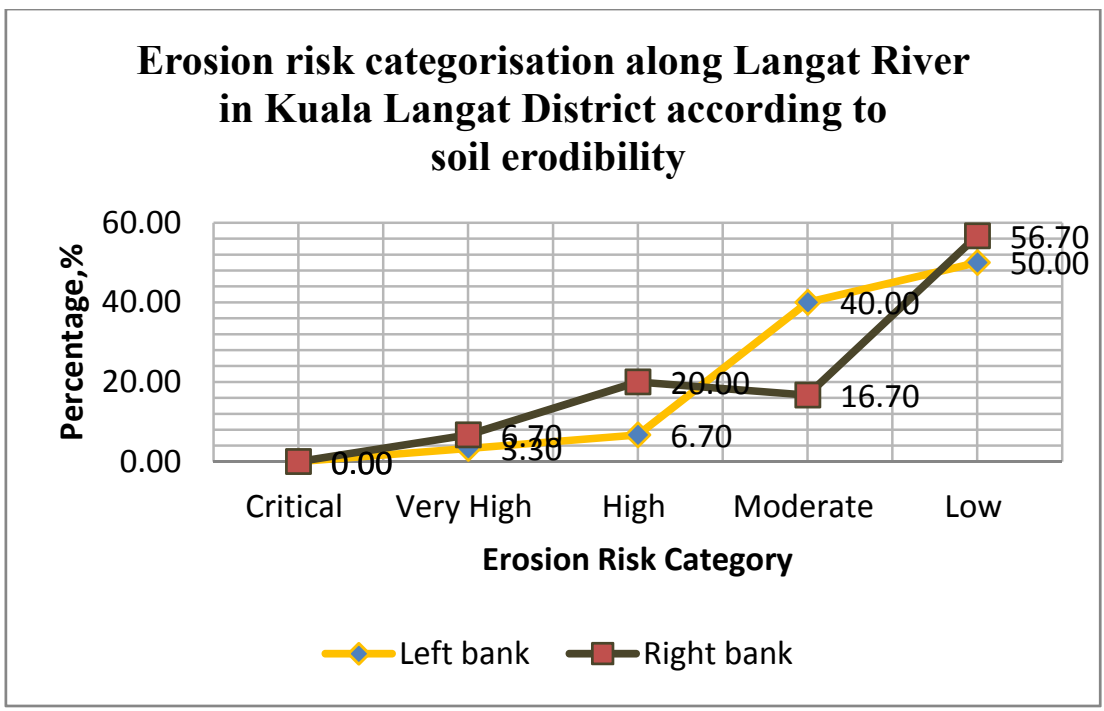

Figure 4: Erosion risk along Langat River in Sepang district. 
study area was categorised as $50.00 \%, 40.00 \%, 6.67 \%$ and $3.33 \%$ of low, moderate, high and very high classification respectively. Meanwhile, the erosion risk on the right bank of the study area was recorded as $56.70 \%, 16.67 \%, 20.00 \%$ and $6.67 \%$ of low, moderate, high and very high category respectively. The results indicate that the right bank of Langat River in Kuala Langat district experienced less erosion risk compared to the right bank. Besides that, no soil sample was categorised as critical degree of erosion risk. This is because the composition of soil texture at Kuala Langat district was clayey soil. It has a greater water holding capacity than sandy soil. In other words, soil with a higher percentage of silt and clay particles has a greater erodibility than a sandy soil under the same condition.

\section{Conclusion}

The study concludes that soils that have more percentage of sand will have a higher risk of failure. This is justified and confirmed by "ROM" scale equation where most of the soil samples were categorised as very high and critical in the degree level of soil erodibility thus leading to riverbank failure. Results also show that for rainfall erosivity values recorded high, very high and critical, the soil erosion potential along Langat River is at risk and vice versa. With this significant finding, suitable mitigating measures can be proposed to prevent prolong serious conditions along the Langat River bank particularly in avoiding stream bank erosion failure. Thus, it would benefit the country in terms of cost reduction in river bank protection. Besides that, the relevant authorities for the respective problematic river bank erosion areas can take early measures to overcome river bank erosion failure.

\section{References}

[1] Roslan Z.A., \& Farid Ezanee, M.G. (2001). Relationship between rainfall erosivity and landslide events. Shah Alam, Selangor: Bureau Research and Consultancy (BRC).

[2] Wischmeier, W.H. \& Smith, D.D. (1978). Predicting Rainfall Erosion Losses - A Guide to Conservation Planning. USDA, Agriculture Handbook No. 537.

[3] Roslan, Z.A \& Mohamad, A. (2012). Forecasting landslide induced erosion. Proceedings from 2nd International Water Resources Management. Langkawi: Malaysia.

[4] Ezemonye, L.N \& Emeribe, C.N. (2012). Rainfall Erosivity in Southeastern Nigeria Ethiopian, Journal of Environmental Studies and Management EJESM Volume 5: No 2.

[5] Wischmeier, W.H. \& Smith, D.D. (1978). Predicting Rainfall Erosion Losses - A Guide to Conservation Planning. USDA, Agriculture Handbook No. 537. 
[6] Caracciola, C., Napoli, M., Porcu, F., Prodi, F., Ditrich, S., Zanchi, C. \& Orlandini, S. (2012). Raindrop size distributions and Soil Erosion, Journal irrigation Engineering 138(5): 461-469.

[7] Wei, W., Chen, L., Fu, B., Huang, Z., Wu, D. \& Gui, L. (2007). The effect of land uses and rainfall regimes on runoff and soil erosion in semi-arid Loess hilly area, China. Journal of Hydrology 335: 247-258.

[8] Morgan, K.M. and Nalepa, R., Application of Aerial Photographic and Computer Analysis to the USLE for Areawide Erosion Studies, J. Soil and Water Cons., 37(6): 347-350, 1982.

[9] Bouyoucos, G.J. (1962). Hydrometer method improved for making particle size analysis of soil. Agricultural journal. 54: 3 .

[10] Roslan, Z.A \& Mazidah, M. (2002). Establishment of Soil Erosion Scale With Regards to Soil Grading Characteristic. $2^{\text {nd }}$ World Engineering Congress, Sarawak, Malaysia, pp. 235-239, 2002. 